\title{
Middelaldertannrot på avveie
}

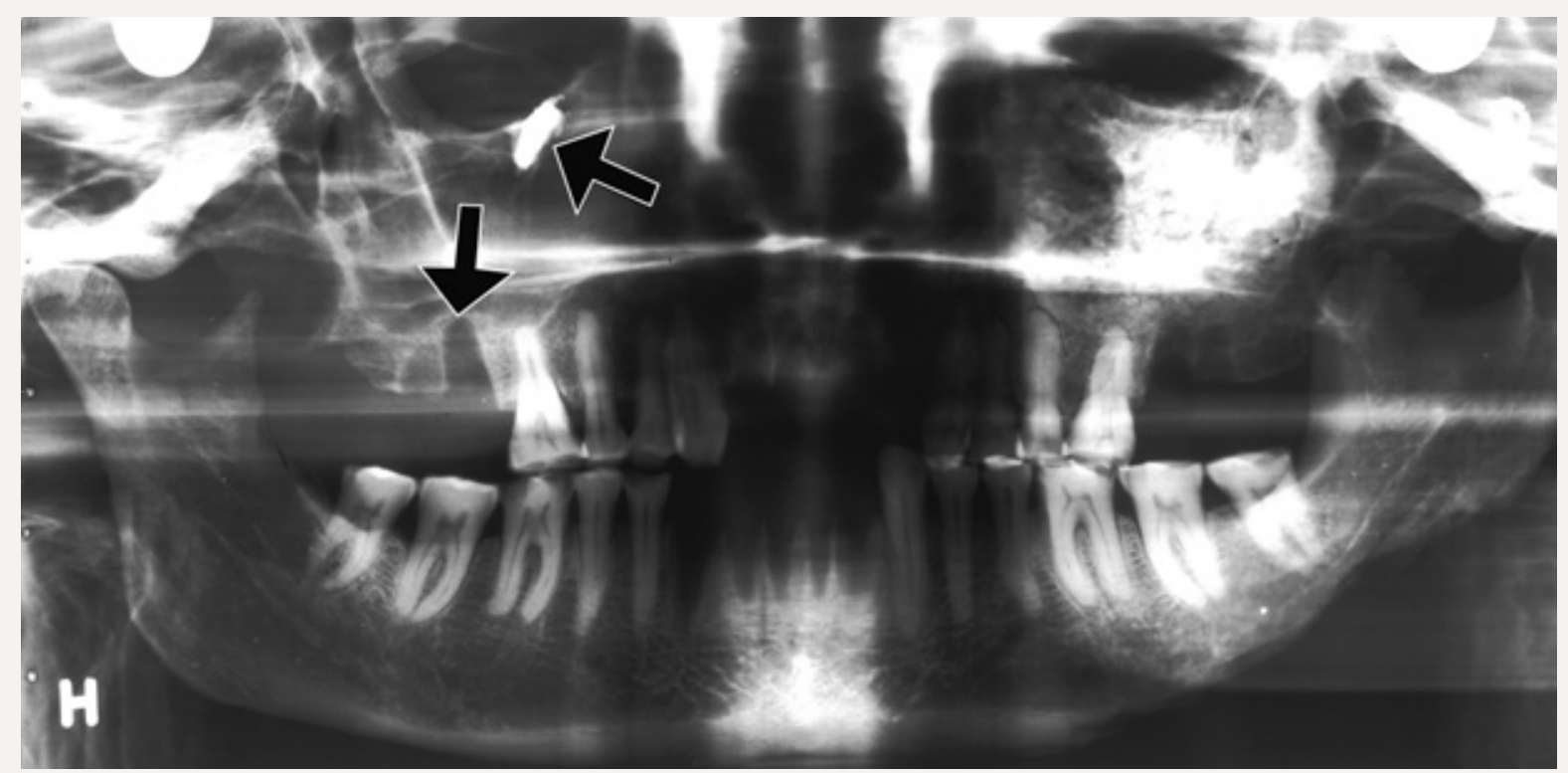

Bildet er fra en røntgenundersøkelse med ortopantomografisk teknikk av et middelalderkranium fra Oslo (De Schreinerske samlinger i Anatomisk institutt). Kraniet, fra en kvinne i alderen 40-60 år, har vært gravlagt ved kirken i Nonneseter kloster. Når hun levde, er ikke sikkert fastsatt. Klosteret omtales første gang i 1161 og synes å ha eksistert i flere tiår etter reformasjonen. $\mathrm{Da}$ Schweigaards gate ble opparbeidet i 1880årene, «traf man saaledes flere skeletter, og $i$ gadens nordre side 82 fod ifra dens sammenstød med Aaslo gade stod et hjørne af kvaderstene,» skrev antikvar Nicolaysen.

Overkjevens molarrøtter har nær anatomisk relasjon til sinus. Dette har stor klinisk betydning i odontologisk praksis. Bildet viser den nære forbindelsen mellom gulvet av sinus maxillaris, seksårsjekselen og den tomme alveolen etter tolvårsjekselen (pil) Høyt i sinus maxillaris, like under orbita, er det en tannrot «på avveier», dislokert til høyre sinus maxillaris (pil). Roten antas å stamme fra tolvårsjekselen.

Det er uklart hvordan tannroten har havnet i sinus maxillaris. Det kan være resultatet av hjemmebehandling som har ledet til aksidentell perforasjon. Middelalderens leger beskjeftiget seg ikke med tenner, og Kirken forbød på det strengeste tannekstraksjon - et inngrep som ble ansett å være farlig. Men det fantes flere «tannverkråd» som kanskje inspirerte til hardhendt egenbehandling i en fortvilet situasjon.

Røntgenbildet viser ellers avslipning av tyggeflatene (okklusal abrasjon), ingen caries og et friskt periodontium. Det skiller seg en del fra tilsvarende røntgenundersøkte kranier fra andre gravplasser i middelalderens Oslo. I de fleste er den okklusale abrasjonen betydelig mer uttalt, og mange har mistet tenner som følge av marginal periodontitt. Det er mulig at forskjellen i dental helse kan ha sammenheng med bedre kosthold i Nonneseter kloster enn i den øvrige befolkningen.

\section{Jacob Klafstad}

jacobklafstad@tele2.no

Amund Hellands vei 2c

1165 Oslo

Oppgitte interessekonflikter: Ingen

Manuskriptet ble mottatt 3.9. 2010 og godkjent 14.10. 2010. Medisinsk redaktør Michael Bretthauer. 